\title{
Modest deviations from optimal adherence to antiretroviral therapy promote residual HIV-1 replication in the absence of virological rebound in plasma
}

\author{
Alexander O Pasternak ${ }^{1 *}$, Marijun de Bruin², Suzanne Jurriaans ${ }^{1}$, Margreet Bakker ${ }^{1}$, Ben Berkhout ${ }^{1}$, Jan M Prins ${ }^{3}$, \\ Vladimir V Lukashov ${ }^{1}$
}

From Frontiers of Retrovirology 2011

Amsterdam, The Netherlands. 3-5 October 2011

\section{Background}

Modern antiretroviral therapy (ART) is assumed to allow a certain degree of nonadherence while still maintaining complete suppression of viral replication ("forgiveness"), as virological suppression, measured by the commercial plasma viral load assays, is common at adherence levels $>55-70 \%$ [1]. Yet, it is unknown whether HIV-1 replication is completely suppressed at these levels of adherence. [2] Here we investigated whether modest nonadherence to ART influences levels of HIV-1 RNA and DNA in peripheral blood mononuclear cells (PBMC).

\section{Materials and methods}

Levels of HIV-1 unspliced RNA (usRNA) and viral DNA were quantified by seminested real-time PCR [2-4] in PBMC of 40 HIV-infected patients who had been on successful ART for a median of 3.8 years before the start of the study and with good immune reconstitution (median baseline $\mathrm{CD} 4^{+}$count, 620 cells $/ \mathrm{mm}^{3}$ ). For every patient, three longitudinal samples, taken with 3-4 month intervals, were analyzed. One-week mean adherence to ART (percentage of prescribed doses taken) prior to the sampling moments was measured electronically.

\section{Results}

Adherence never fell below7O\% in any patient, and concurrent plasma viral loads of 109/120 (91\%) PBMC

${ }^{1}$ Academic Medical Center of the University of Amsterdam, Medical

Microbiology, Amsterdam, Netherlands

Full list of author information is available at the end of the article samples were undetectable $(<50 \mathrm{cop} / \mathrm{ml})$; for $10 / 11$ remaining samples they were $<100 \mathrm{cop} / \mathrm{ml}$. Longitudinally, 23 patients were constantly $100 \%$ adherent, eight demonstrated improving adherence in time, and nine ("poor adherers") showed decreasing, variable, or constantly $<100 \%$ adherence. Notwithstanding the lack of virological rebound in any of the patients, poor adherence, but not optimal or improving adherence, caused a significant longitudinal increase in usRNA levels $(P=0.006)$. Remarkably, the change in adherence patterns from optimal through improving to poor was paralleled by a gradual increase in the corresponding viral RNA trends. Significant differences between the poor adherers and the remaining patients were observed in time-weighted changes from baseline $(P=0.0006)$ and regression slopes $(P=0.009)$ of usRNA, but not of viral DNA. These effects were independent of the therapy regimen or the time of virological suppression. Same effects were observed in a subset of patients whose plasma viremia was constantly undetectable $(n=30)$.

\section{Conclusions}

As ART only blocks the infection of new cells, but not viral RNA transcription in infected cells, the observed effect of decreased ART pressure (resulting from decreased adherence) on HIV RNA levels in PBMC strongly suggests new replication cycles despite ART, and not simply enhanced HIV-1 transcription in cells infected prior to therapy initiation. Our results represent the first evidence indicating that constant optimal 
adherence to modern ART may be necessary to stop all HIV replication.

\section{Author details}

${ }^{1}$ Academic Medical Center of the University of Amsterdam, Medical Microbiology, Amsterdam, Netherlands. 'University of Wageningen, Communication Science, Wageningen, Netherlands. ${ }^{3}$ Academic Medical Center of the University of Amsterdam, Internal Medicine, Amsterdam, Netherlands.

Published: 3 October 2011

\section{References}

1. Shuter J: Forgiveness of non-adherence to HIV-1 antiretroviral therapy. J Antimicrob Chemother 2008, 61:769-773.

2. Shen L, Siliciano RF: Viral reservoirs, residual viremia, and the potential of highly active antiretroviral therapy to eradicate HIV infection. J Allergy Clin Immunol 2008, 122:22-28.

3. Pasternak AO, Adema KW, Bakker M, Jurriaans S, Berkhout B, Cornelissen M, Lukashov W: Highly sensitive methods based on seminested real-time reverse transcription-PCR for quantitation of human immunodeficiency virus type 1 unspliced and multiply spliced RNA and proviral DNA. J Clin Microbiol 2008, 46:2206-2211.

4. Pasternak $A O$, Jurriaans $S$, Bakker M, Prins JM, Berkhout B, Lukashov W: Cellular levels of HIV unspliced RNA from patients on combination antiretroviral therapy with undetectable plasma viremia predict the therapy outcome. PLOS ONE 2009, 4:e8490.

5. Pasternak AO, Jurriaans S, Bakker M, Berkhout B, Lukashov W: Steady increase in cellular HIV-1 load during the asymptomatic phase of untreated infection despite stable plasma viremia. AIDS 2010, 24:1641-1649.

doi:10.1186/1742-4690-8-S2-O35

Cite this article as: Pasternak et al:: Modest deviations from optimal adherence to antiretroviral therapy promote residual HIV-1 replication in the absence of virological rebound in plasma. Retrovirology 20118 (Suppl 2):035.

\section{Submit your next manuscript to BioMed Central and take full advantage of:}

- Convenient online submission

- Thorough peer review

- No space constraints or color figure charges

- Immediate publication on acceptance

- Inclusion in PubMed, CAS, Scopus and Google Scholar

- Research which is freely available for redistribution

Submit your manuscript at www.biomedcentral.com/submit
C Biomed Central 